\title{
REACTOR PHYSICS CALCULATIONS FOR APPLICATIONS IN NUCLEAR TECHNOLOGY
}


This page is intentionally left blank 


\section{Workshop on \\ REACTOR PHYSICS CALCULATIONS \\ FOR APPLICATIONS IN \\ NUCLEAR TECHNOLOGY}

12 Feb - 16 Mar 1990 International Centre for Theoretical Physics Trieste, Italy editors

\section{E Cullen}

Lawrence Livermore National Laboratory USA

R Muranaka

International Atomic Energy Agency Austria

J Schmidt International Atomic Energy Agency Austria 
Published by

World Scientific Publishing Co. Pte, Ltd.

P O Box 128, Farrer Road, Singapore 9128

USA office: 687 Hartwell Street, Teaneck, NJ 07666

UK office: 73 Lynton Mead, Totteridge, London N20 8DH

Library of Congress Cataloging-in-Publication data is available.

\section{WORKSHOP ON REACTOR PHYSICS CALCULATIONS FOR APPLICATIONS IN NUCLEAR TFCHNOIOFY}

Copyright $\odot 1991$ by World Scientific Publishing Co. Pte. Ltd.

All rights reserved. This book, or parts thereof, may not be reproduced in any form or by any means, electronic or mechanical, including photocopying, recording or any information storage and retrieval system now known or to be invented, without written permission from the Publisher.

ISBN $981-02-0517-1$

Printed in Singapore by Utopia Press. 


\section{PREFACE}

The Workshop on Reactor Physics Calculations for Applications in Nuclear Technology 12 February through 16 March 1990, was organized by I.C.T.P. in cooperation with the Nuclear Data Section of the I.A.E.A., Vienna.

Although fission reactor calculations have been performed for the last forty years the methods used are continually being improved and advances in computers now make it possible to perform calculations which were not economically feasible in the past. This continuous evolution of methods and computer codes makes it important to periodically hold workshops to allow participants to become familiar with the state of the art in reactor calculations.

This workshop was designed to meet the needs of participants who are currently involved in or are planning a nuclear programme involving research and/or power fission reactors. In order to meet the needs of participants the workshop had a broad scope including not only fission reactor core calculations, but also safety, fuel management, waste disposal, reactor licensing, etc. As such the lectures and computer exercises covered almost all aspects of the operation of fission reactors and these proceedings present a view of the state of the art of fission reactor calculations.

This workshop introduced participants to the methods currently used in fission reactor calculations and to some computer codes in which these methods are used. The workshop was composed of lectures each morning followed by computer exercises each afternoon. The participants were thus able not only to become familiar with methods, but also to actually perform computer calculations of exercises prepared by the lecturers as well as calculations of interest to the individual participants.

The organizers of this workshop wish to thank the staff of the International Centre for Theoretical Physics, Trieste and the Nuclear Data Section IAEA, Vienna for the assistance that they provided in preparing for this workshop as well as in conducting the workshop. Their assistance contributed greatly toward the success of this workshop and their efforts are much appreciated. 


\section{CONTENTS OF PROCEEDINGS}

In these proceedings we have attempted to include, as much as possible, the material which was presented during the workshop. We have attempted to make the proceedings self-contained and intelligible, not only to workshop participants, but also to individuals who were not present during the workshop lectures.

The printed material distributed to the workshop participants may be grouped into three broad classes, (1) lecture notes prepared specifically for presentation during the workshop. (2) copies of the transparencies which were used by lecturers during their presentations. (3) background material and reports which have been previously published.

Of the material distributed during the workshop we have included in these proceedings, (1) all lecture notes which are of publishing quality (e.g., no hand-written lecture notes), (2) copies of transparencies only if they are self-explanatory or accompanied by explanatory text, (3) references to all previously published background material and reports.

The editors wish to thank the lecturers for the promptness with which they provided the final copies of their lecture notes. The editors also apologise if their attempts to make the proceeding selfcontained and intelligible have resulted in any material being excluded from these proceedings. 


\section{CONTENTS}

Preface

Nuclear Data - Their Importance and Application in Fission Reactor Physics Calculations

J. J. Schmidt

Activities of the NEA Reactor Physics Committee and

International Benchmark Studies for Reactor Physics Codes Enrico Sartori

Activities of the OECD/NEA Data Bank and

Its Computer Program Service

Enrico Sartori

NJOY: A Comprenhensive System for the Processing of ENDF Formatted Nuclear Data

Douglas W. Muir

NYOY - 89: Computer Exercises

Douglas W. Muir, R. MacFarlane

Evaluated Nuclear Data Processing and Nuclear Reactor Calculations Andrej Trkov

Basic Reactor Physics

S. H. Levine

Lattice Cell Calculations, Slowing Down Theory and

Computer Code WIMS; VVER Type Reactors

T. Kulikowska

Preparation of Input for the WIMS Code

B. Sadowska

In-Core Fuel Management: PWR Group Constants Generation Using PSU-LEOPARD Code

D. Pevec 
In-Core Fuel Management: PWR Calculations Using MCRAC

B. G. Petrovic

Nuclear Safety Parameters of Mixed TRIGA Cores

M. Ravnik

Optimization of TRIGA Reactor Operation Using Reactor Calculations

I. Mele

Computer Code ANISN Multiplying Media and Shielding

Calculation I - Theory

J. R. Maiorino

442

Computer Code ANISN Multiplying Media and Shielding Calculation II - Code Description (Input/Output)

J. R. Maiorino

Computer Code ANISN Multiplying Media and Shielding Calculation III - Sample Problems

J. R. Maiorino

Inverse Point Kinetics for the Reactivity Determination - Description of the KINIK Code

R. Nabbi

562

Fluid Flow and Heat Transfer Model of the HEATHYD Code R. $N a b b i$

Reactor Neutron Dosimetry - Radiation Damage Estimates for Reactor Structural Materials

N. P. Kocherov

Reactor Neutron Dosimetry - Calculation Methods in Neutron Spectrum Unfolding

N. P. Kocherov

Reactor Neutron Dosimetry - Past, Present and Future

N. P. Kocherov 
Advances in Personal Computers for Scientific Applications

Dermott. E. Cullen

654

Review of Research Reactor Safety Documentation Developed

by the International Atomic Energy Agency

N. G. Chrysochoides

668

List of Lecturers and Participants

725 